\title{
R.マレ=ステヴァンスの建築理念に関する考察 \\ A STUDY ON THE ARCHITECTURAL CONCEPT OF R. MALLET-STEVENS
}

\author{
阿部順子*，小林 克弘** \\ Junko ABE and Katsuhiro KOBAYASHI
}

\begin{abstract}
The purpose of this study is to make clear the architectural concept of a French modern architect R. Mallet-Stevens. What was the most important for him was to match his architecture to the times in which he lived. He was willing to adopt decorative elements, such as le vitraux blanc (white stained glass), if they were original and creative. He regarded his architecture as a geometrical sculpture. He did not provide any clear reason for his concept, but it is sure that the figure he created has realised the strong contrast of light and shadow, which he loved.
\end{abstract}

Keywords: Mallet-Stevens, modern architecture, architectural concept, France マレンステヴァンス、近代建築、建築理念、フランス

1.はじめに

目的：本稿の目的は、フランスの近代建築家ロベール・マレ＝ス テヴァンス (Robert MALLET-STEVENS 1886-1945) の建築 理念を、彼の著述の分析を通じて明らかにすることである。マレ= ステヴァンスは自らの建築理念をまとまった著作の形で残さなか ったため、彼の建築理念はわかりにくく、かい、よく知られている と山言えない。彼の作品についての既往研究(1)、特に、J F.PINCHON 編、"Rob.Mallet-Stevens, architecture, mobilier, décoration" ( Phillipe Sers Editeur, Paris 1986) では興味深い 論 がいくつも展開されている。ただ、これらは、都市論、装飾論、幾 何学と理論等、部分的な考察であり、マレ=ステヴァンスの言説を 丁寧に研究しているものではない。

方法：本稿で分析の対象とした著述（表1）は、主に彼の雑誌寄 稿記事で、既に知られているものに著者が新たに発見した 7 編を加 えたものであるめ。すす、文脈に注意しつつ、彼の建築に対する考 え方が示されている部分をこれらの著述から抽出し、それをテいマ 毎にグルーピングし項目をつけた。これらの項目は、(1)近代建築に 関する理念、(2)装飾に関する理念、(3)造形に関する理念、という3 つのテーマに収束すると判断し得た。(1) 很の建築観を示すだけ
ではなく、近代建築の潮流に㧍ける彼の位置を考察する一助とも なろう。(2)は、彼の作品の大きな特徽である装飾要素に対する彼の 見解を示寸重要なテーマである。(3は、彼の凹凸の多、箱型の造形 の理由を示晙する。よって、これらの3点はマレシスデヴァンスの 建築家としての個性を捉える上で啇切であると判断されるので、2 章以降各章毎で考察することとした。以下の引用の「の後の番号 は（表 1) の番号に一致し、出典を示す。

近代建築家としてのキャリア : 建築理念の理解の一助として、建 築家としてのキャリアを以下に概説したい。マレ＝ステヴァンスは、 第一次と第二次世界大戦の間にパリを中心に活躍した、フランスの 代表的な近代建築家の一人である。代表作には、パリ16区のマレ =ステヴァンス通りの住宅群（1926-27 年）(図1)、アール・デコ 博（1.925 年）とパリ万博（1937 年）のパヴィリオン等があるは。 彼の作品の多くは、古典的装飾がない、概ね白い箱型の建築で、一 見、国際椂式の建築の様であるが、しばしば芸術家によるステンド グラスやメタルワークといらた装飾的要素をもつ。

彼は有力な画商の家に生まれ、パリ近郊に育った。ブリュッセル のストックレー邸の施主アドルフ・ストックレーは叔父にあたり、 彼はストックレー邸を建築中から数回訪れ《、1923 年頃までは、ゼ
* 東京都立大学大学院工学研究科建築学専攻 大学院生・修士 (工学)

** 東京都立大学大学院工学研究科建築学専攻 教授・工博
Graduate Student, Dept. of Architecture, Graduate School of Engineering, Tokyo Metropolitan University, M. Eng.

Prof., Dept. of Architecture, Graduate School of Engineering, Tokyo Metropolitan University, Dr. Eng. 
（表 1) マレ=ステヴァンスの著作リスト

$$
\text { 奴ト }
$$

\begin{tabular}{|c|c|c|c|c|c|c|c|c|c|}
\hline 1) Pour comprendre une ville, Guérante & & 1904 & & |- & & & & & \\
\hline 2 L'Art contemporain & Le Home & 1911 & $31-$ May & & & & & & \\
\hline 3 Le Trace des villes. L'infuence de l'architecture sur & Tekhné & 1911 & $21-$ Sep & no26 & o & & & & \\
\hline 4 Le salon d'automne & Tekhné & 1911 & $26-0 \mathrm{ct}$ & no31 & & & & & \\
\hline 5 Le noir et blanc & Tekhné & 1911 & 16 -Nov & no34 & & & & & \\
\hline 6 La sculpture et larchitecture & Tekhné & 1911 & $23-$ Nov & no35 & o & & & & \\
\hline 7 Les animaux et la décoration & Tekhné & 1911 & $30-\mathrm{Nov}$ & no36 & to & & & & \\
\hline 8 extraits & Gazette des Sept Arts & 1922 & 15-Dec & & & & & & \\
\hline 9 L'architecture au salon d'automne & Gazette des Sept arts & 1923 & O1-Nov & no9 & & & & & \\
\hline 10 Les caractéristiques des larchitecture moderne & \begin{tabular}{|l|} 
Gazette des Sept arts \\
\end{tabular} & 1923 & $25-\mathrm{Jan}$ & no2 & & & & & \\
\hline 11 Architecture et géométrie & Bulletin de la vie artistique & 1924 & & no23 & & & & & \\
\hline 12 interview de Guillaume Janneau : formes nouvelles et programmes nouveaux & & 1924 & & & & & & & \\
\hline 13 F.L.Wright et l'architecture nouvelle & Wendingen & 1925 & & no.spécia & 10 & & & & \\
\hline 14 Les raisons de l'architecture moderne(conférence) & Confé rencia & 1925 & $01-\mathrm{Dec}$ & no24 & o & & & & \\
\hline 15 Le cinéma et les arts, Parchitecture & \begin{tabular}{|l|l} 
Cahiers du mois \\
\end{tabular} & 1925 & & & & & & & \\
\hline 16 L'architecture au salon des indépandants & Gazette des Sept arts & 7925 & $10-\mathrm{Feb}$ & no3 & & & & & \\
\hline 17] Les vitraux de Barillet & Les arts de la maison & 1926 & & printemps & & & & & \\
\hline 18|Régionalisme & Confé rencia & 1926 & dec & no24 & & & & & \\
\hline 19| Interview: Sur la crise de logement & La construction moderne & 1927 & 13-Mar & & & & & & \\
\hline 20 réponse à une enquête sur la loi Loucheur & Monde & 1928 & 04-May & no29 & & & & & \\
\hline 21 L'Eclairage et l'architecture moderne & LUX & 1928 & & & & & & & \\
\hline 22 Grandes constructions, L'art international d'aujourd'hui & Charles Moreau & 1928 & & - & & & & & \\
\hline 23 réponse à notre enquête & L'architecture d'aujourd'hui & 1930 & & not & & & & & \\
\hline 24 Les aéroports & \begin{tabular}{|l} 
Larchitecture d'aujourd'hui \\
\end{tabular} & 1931 & dec & no.spécia & & & & & \\
\hline 25 Défence de l'architecture et de la décoration moderne & L'architecture d'aujourd'hui & 1931 & apr-may & not & & & & & \\
\hline \begin{tabular}{l|l}
26 & Architecture moderne (Le Mois) \\
27 & \\
\end{tabular} & L'architecture d'aujourd'hui & 1932 & nov & no8 & & & & & \\
\hline 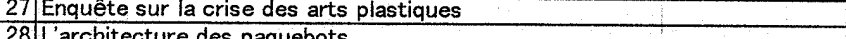 & LExcelsior & 1932 & 28-Dec & & & & & & \\
\hline $\begin{array}{l}28 \mid \text { L'architecture des paquebots } \\
29\end{array}$ & Paris-Soir & 1933 & $16-\mathrm{Jan}$ & & & & & & \\
\hline 29 Enquête: Evolution ou mort de lornament? & Art et dé coration & 1933 & jul-aug & no6 & & & & & \\
\hline 30 Enquête du peintre Angle & L'architecture d'aujourd'hui & 1933 & jul-aug & no6 & & & & & \\
\hline 31 Une collaboration des architectes avec les peintres at les sculptuaurs est-elle possible? & Art et de coration & 1933 & fév & & & & & & \\
\hline $\begin{array}{l}32 \\
32\end{array}$ & L'architecture d'aujourd'hui & 1934 & mar & no2 & & & & & \\
\hline 33 En vue de l'expo de 1937, Le concours des Musées d'Art moderne & L'architecture d'aujourd'hui & 1934 & dec-jan & noto & & & & & \\
\hline 34 Enquête: Avons-nous un style d'ameublement? & Mobilier et dé coration & 1934 & & & & & & & \\
\hline 35 Normandie 1935 & L'architecture d'aujourd'hui & 1935 & aug & no8 & & 0 & & & \\
\hline \begin{tabular}{l|l|}
36 & Architecture d'aujourd'hui \\
37
\end{tabular} & L'architecture d'aujourd'hui & & sep & no9 & $\circ$ & & & & \\
\hline 37 Le trocadéro et l'expo de 1937, une discussion au club faubourg & L'architecture d'aujourd'hui & 1936 & & & o & & & & \\
\hline 38 L'éclairage public de Paris & L'architecture d'aujourd'huil & 1937 & & no5-6 & & o & & & \\
\hline 39] U.A.M. & L'architecture d'aujourd'hui & 1937 & & no7 & & & & & \\
\hline \begin{tabular}{l|l}
40 & Les Expositions passées \\
41 Introduction Vitraty
\end{tabular} & Larchitecture d'aujourd'hui & 1937 & & no1-2 & & - & & & \\
\hline 41 Introduction: Vitraux modernes/expo.international de 1937 & Charles Moreau & 1937 & & & & & & & o \\
\hline 42 Les restaurants & L'architecture d'aujourd'hui & 1938 & dec & no12 & & 0 & & & \\
\hline 43 La mode et le moderne & & 1938 & & & & & & & \\
\hline 44 sur l'Angleterre, l'Angleterre, Londre & $?$ & & $E$ & - & & & & & \\
\hline \begin{tabular}{l|l|}
45 & L'Esprit des expositions \\
46 & Fnseignement des Reaur-Arts en France
\end{tabular} & L'architecture d'aujourd'hui & 1940 & & nol-2 & & & & 10 & \\
\hline Beaux - Arts en France & & 1940 & - & & & 으 & & & \\
\hline $\begin{array}{l}\text { 47 sur l'organisation de la profession, La reconstruction de } r \\
48 \text { Architecture, les cinemas }\end{array}$ & & 1940 & & $=$ & & & & & \\
\hline 48|Architecture, les cinémas & Musée Galliera, Paris & 1924 & & & & & & & \\
\hline
\end{tabular}

\section{ビブリオ凡例 :}

$M$ : Jean-François PINCHON, Rob.Mallet-Stevens, architecture, mobilier, dé coration, Philippe Sers Editeur, Paris 1986

B: Christian BONNEFOI, "Rob.Mallet-Stevens; positions et contradictions de l'archietcture internationale", Thèse de doctorat, Université de Paris I, 1974

N: Cécile BRIOLLE, La villa Noailles: Mallet-Stevens, Editions Parenthèses, Marseille 1990

A: Rob.Mallet-Stevens architecte, Editions des Archives d'Architecture Moderne, Bruxelles 1980

ᄂ： マレニステヴァンスの作品（旧 maison Trapenard (1931年)）の現所有者であるLongepied氏のビブリオ Ј: 著者

\section{ツェッションの影響を感じさせるドローイングを残している。}

建築教育を受けたのは、ボザールより、より実務的なカリキュラ ムをもっていた、パリの私立のエコール・スペシアル・ダルシテク チュール (ESA:Ecole Spéciale d'Architecture) で、「2番で入学し、 1 番で卒業した」の（1904-06 年在学）。

卒業後は、展覧会活動や雑誌への埥稿をし、第一次世界大戦中 1914 年から約 2 年半は、空軍で航空観察写真撮影を任務としてい た。戦後は、まずインデリアや映画セットをデザインをした。映画 セットは、1920 年代を通じて 15 作品以上手掛け、セットデザイナ 一としても大きな成功を収めた(6)。

建築家でありながら、かい、あろうとしながらも、そのキャリア のスタートの数年間はインテリアデザインが中心であった。しかし、 このような境遇も、彼の、調度品も含めた総合的な内部空間の設計 に対する強い関心、志向にも合致していたものと思われる。この彼 の関心や志向は、調度品、壁紙、照明器具などが丹念に描か沉てい るインテリアデザインのドローイングに見ることができる(図2)。 マレニスデヴァンスの、この比較的狭い空間への執着は、一方で建
物単体への関心となり、都市構造への関心の薄さへと通じる。彼 はル・コルビュジエのように都市の提案を打ち出すことはなく、都 市に関するプロジェクト自体、「ある現代都市 une cité moderne」 (1922 年、24 年) (図3)、「ポルト・マイヨのコンペ」(1937 年) 等位で、非常に少ない。特に前者は、劇場、駅、市庁舎といった都 市施設のドローイング集で、都市構造への視点はない。パリ近郊に 生まれ、パリを主たる活躍の場とした彼にとって、「ヴォアザン計 画」のような都市構造の大変革はリアリティのないものに感じられ たろうし、そもそも彼にとって都市は生しろ個性ある建築物や広場 によって、把握、諗知されるものと考えられるの。

彼の建物単体への関心は、1923 年から 1937 年頃という比較的 短、実務キャリアのなかで、多彩なビルディングタイプの設計を手 懸けることで、具現化された。レストラン、靴屋、カフェ、ガレー ジショールーム、劇場、といった商業建築、個人住宅、集合住宅、 博覧会のパヴィリオン、消防署、蒸留所といった作品を次々実現し たことは、彼の近代建築家としての一つ大きな特徴である。この 多彩さには、様々なシーンを創出する映画セットデザインと共通し 


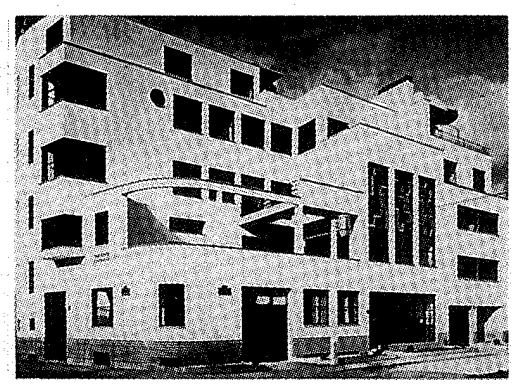

(図1)マレ＝ステヴアンス自邸(1927) 図版出典: 注(1)(3) p.39

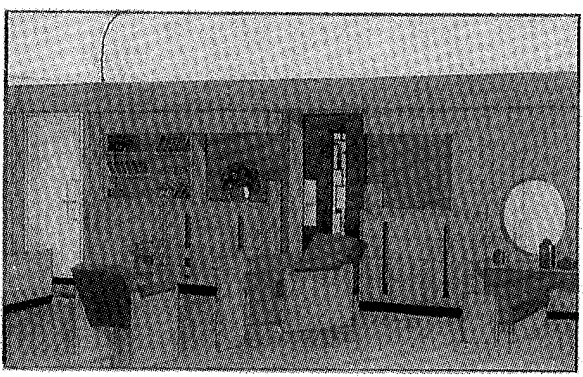

(図2)「2つのベッドのある寝室」(1929) 四版出典: 注(2)(3) p.28

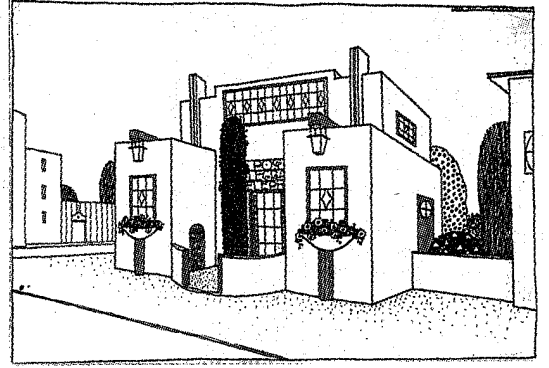

(図3)「『ある現代都市』より一郵便局」(1922) 図版出典: 注(1)(2) p. 185
た志向をみることができる。この志向は、自らの建築家としての造 形上のエゴを満たすよりも、実際的な効果、機能にあった建築を実 現したがる志向であり、これもマレ=ステヴアンスの注目すべき特 徴の一つである。

当時のフランスの建築界においては、彼は、近代芸術家連合 (UAM: Union des Artistes Modernes、1930 年設立、以下UAM とする）を創立する等、ル・コルビュジェと並ぶアヴァンギャルド の代表的な存在であり、最も有力なイデオローグの一人であっため

\section{2. 近代建築に関する理念}

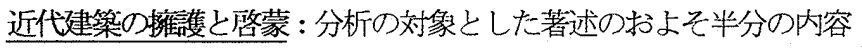
は、近代建築 architecture moderne の擁護と啓蒙である。これらの 著述加、1920年代加 30 年代にか外て、近代建築が徐々に社会 に受け入れられていくものの、1920 年代屾大衆の近代建築への無 関心に、1930 年代は台頭するナショナリズムによる近代建築批判 に彼が抵抗しなければならなかったことがわかる。

近代建築の定義：と汹いえ、マレ＝スラヴァンスは近代建築の必 要性、重要性を熱心に説くものの、その近代建築がどのようなもの なのか明確に、もしくは繳密に定義することはなかった。著述には 以下の定義が見出せたが、これらはどれも漠然としている。

[定義 1] 近代建築は幅広いものである。一般的な傾向は、(1)ン プルであること、(2)造形的な穞やかさ、(3)想像力（No.9 : サロン・ ドーートンヌに出品された模型について）

[定義 2] 近代建築の特徽簢単に言えば、以下のようにまとめる ことができるだろう。（1幾何学的なヴォリュームの組み合わせ、(2) 立方体・球面、(3)正六面体 (No.10)

[定義3] (1)統一性、(2)シンプルなオリジナリティ、(3)今後頭角を 現すスタイル (No.13)

シンプルであること:それでも上記の定義加ら共通して読多取れ るのは「シンプルであること」への志向である。シンプルであるべ き理由は、例えば以下の記述に兒ることができる。

「現代芸術山ゆえにシンプルである。

I : それてが、その黎明にあるから(の)

$\Pi$ I : 今日の人間には穏やかさと静かさ、休養が必要だから

III : 流行を反映する装飾はロストがかかるから

IV : しばしば壮大で、贅を凝らした城はもはや顧客を持たないから $\mathrm{V}:$ : 現在の建設材料（鉄と鉄筋コンクリート）は建築の飾りが役立 たずになるように、十分に装飾的な形態を可能にする。陰影の効果 を自らつくる後退されたヴオリュームは、昔の、飾られた立方体に とって代わったから」(No.28)

I とIIはやや然意的な、II とIV外多くの機能主義者に見られる現
実的な、しかしありふれた理由である。注目すべきはVで、これは、 近代建築家らしく、近代の建築技術がもたらした新しい美をマレ= ステヴァンスが肯定していることを示す。それは「新しい建築の手 本は、近代技術の実現の中に探されなければならない」(No.28)、

「鉄々建設技術の中で主人として君跣していた。その間に、アメリ カ人の技術者は、壮麗な工場を建設していた。いくうかの工業建築 湋大な美をもつている。鮮明で、明解なプログラム、健全で経済 的なコンセプト、不可欠な論理が感じられる。極めて快い美学が首 尾一貫している。これが真の憈偽りのない建築である」(No.13) と いう記述にも見られる。

モダンであること：もう一、マレ＝ステヴァンスの近代建築観に おいてはっきりみられるのが「モダンであることêtre moderne」 の志向である(1の「「モダンであること」とはつまり、「その時代に 合致していること、その時代の要請を理解すること」 (No.43) で ある。彼が代表を務めた U.A.M の活動目的についても、「U.A.M は《びっくりさせる》ためでなく、その時代に合致するために先頭 をきってきた。経済・社会の問題は、U.A.M を無関心で流いさせな からた。：一軒の家、ひとつの椅子、ひとつの彫刻は今日、昨日の それとは異なって《いなければならない》」(No.39) と述べる。

「新しいニーズがある。新しい技術がある。美学は新しいリ (No.22) と、時代に即寸るために、生活様式や建設技術の変化に併せて、建 築も変わらなけ机ばならず、それこそが「新しい時代の新しい建築 二近代建築 」であるとマレ=ステヴァンスは考えるのである。

先に述べたように、彼は近代建築について明確な定義をしなかつ た。彼の考える近代建築が定義ししてまとめるには、あまりに多様 であったことは以下の記述から読み取れる。

「彼らの実施作品・計画によって、私達は何が明日の建築となるか 予見する。もし、それぞれが個性をもっているとしても、全ての人 間は同様の方法を、近代去術の最も偉大な財産のためのものを認識 するのだ。フランスのボニエ、トニー・ガルニェ、ルヴァール、ル トロスヌ、マリーニ、ペレ兄弟、プリニメ、ルビーニ、ルオー、セ ジ二、シタリス、ティエール等、外国のキアットーネ、ヴァン・ド ウースブルグ、ジャンヌレ、アウト、サンテリアは新しい建築の同 じコンセプトを持っている」(No.10)(11)、「F．L．ライトはアメ リカ人である。モー壮一汭イ人、ドュドックはオランダ人、グ ロピウスはドイツ人、ペレはフランス人である。彼らの建築はモダ ンである。いくつかのディデールが、その国民性を与えるとしても、 そのコンセプトは《現代的 contemporaine》である。彼らの建筑は 《今日の d'aujourd'hui》人閒のために、《今日の》人間によって考 案されているのだ」(No.36)。つまり、マレ=ステヴァンスは 19 世紀末以降の一連の建築を、建築家毎の個性、地域性による差異を 


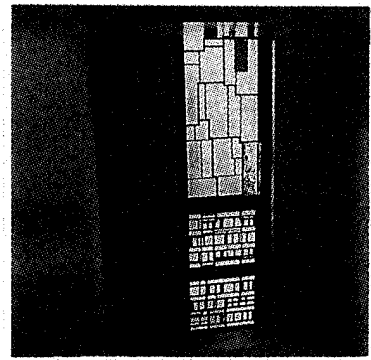

(図4)ドレフュス邸階段室(1927) 著者撮影

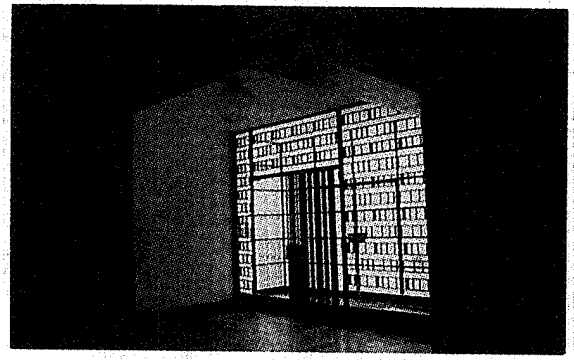

(図5)ドレフュス邸エントランス(1927) 著者撮影

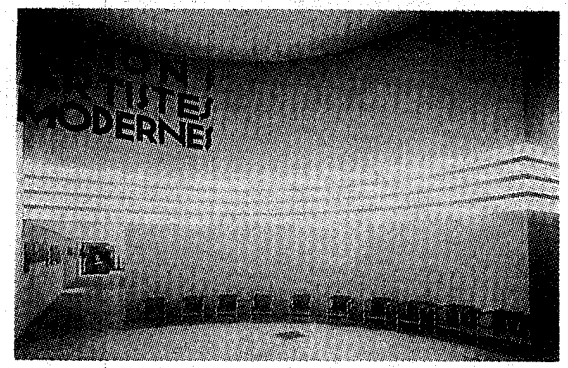

(図6)UAM 第一回展覧会エントランス(1930) 図版出典: 注(1)(2) p. 310
認めつつも、ひとつのまとまり二新しい建築、として捉えていたこ とがわかる。これは現在「近代建築」と総称されるものであり、彼 にとっては、アール・デコ寄りの建築家も、デ・スティルも、ル・ コルビュジェもライトも同様に「モダン」であり、「モダンである」 ということが重要で、形態上の差異、造形のコンセプトの差異は大 きな問題ではなかった。さらに、ここで注意しなければならないの は、彼にとっての近代建築は、後に国際様式として一般的になる動 向とは必ずしも一致しないということである。「モダンであること」 というのは、かなり大きなくくりなのである。なお、意外なことに、 伝統を守るボザールに対する批判はほとんどない。

彼の近代建築の概念はこのように多様な広がりを許容するもの であったが、では、彼自身の近代建築はどのようなものであったの だろうか。以降、彼の建築の特徵について考察をすすめたい。

\section{3. 装飾に関する理念}

無装飾の印象を与える建物に、装飾的要素が空や扉等に限定的 に使用されている。これが、彼の建築の特徴である反面、彼の装飾 に対する態度をわかりにくくしてきた。以下、マレ=ステヴァンス 自身は装飾についてどのように考えていたか整理して述べる。 装飾への熊度 : 彼は、もちろん全ての装飾要素を否定しているので はない。ごく初期の著述では、「何人かの建築家達は、インテリア に装飾の観点から、動物をどんなにすばらしい利用ができるか理解 しはじめている。（中略）家の中で、動物は、色の点であり、花の ごとく、材料の豪華さに生活の美を加える」（No.45）、また、1930 年代にも、旗、花、光る噴水泉、噴水汁博覧会の背景である。これ らは陽気さの要素である」（№.7）と装飾要素を肯定する。また、 建築に密着している彫刻は、ある種の装飾要素と考えるのが自然で あるが、マレニステヴァンスは「雕刻を飾りと理解してはいけな い。：リュドゥのラ・マルセイエーズ la Marseillaise de Rude、カ ルポーのラ・ダンス la Danse de Carpeaux、シャンゼリゼ劇場のブ ールデルのフリーズ la frise de Bourdelle au Théâtre des ChampsElysées は、飾りではない（№.29）と装飾要素とは認めないもの の、積極的に自作に取り入れていることを表明している No.29）。 これもある種の装飾の肯定といえる。

しかしながら、マレ＝ステヴァンスの作品は古典的な装飾を一切 もたないし、その平滑な壁面や、幾何学的な造形はむしろ無装飾と いう印象を与える。実際、1934 年のインタビューでは、以下のよ うに指摘される。

「インタビューア：しかしながら、あなたは本来の意味での装飾を 拒否しました。

マレニスデヴァンス:ある種の装飾を、です。革新の欲冰によっ
て確が飾るということは再生するだろうということに注目し て下さい。第一に全てを指揮し、核心を秩序付け、存在条件に適 合する建築があります。それから、全く恣意的で流行のきまぐれ をうける、流行それ自体である装飾がある。だからいりも新しい 様相の創造が欲されるときは、装飾的創意を探求す心゙きでしょ

\section{引」 (No.34)}

ここで、マレ=ステヴァンスが否定する「ある種の装飾」とは、 (1)過㮃で染意的な装飾 (No.13) 、 (2)流行に過ぎないもの (№.29)、 (3)古典的オーダー (No.22)、であろう。逆に肯定する装飾とは「創 意ある、新しいもの」と考えられる。つまり、コピーに過ぎない過 剩な装飾は排除すべきだが、創意があつて新鮮な装飾は取り入れる べき、ということである。

白いステンドグラス：この「創意ある、新しい装飾」とはマレ= ステヴァンスにとって、具体的には例えば、「白いステンドグラス le vitrail blanc」(図4)である。彼の、このステンドグラスへの思い 入れは強く、112 世紀の、その創成期から今日まで、ステンドグラ スはいりも建築の忠実な相棒であった。（中略）新しいプログラム、 新しい材料が、真新しい建築を開花させた今日、ステンドグラスは 蘇る」 (No.41)、「光る《ボード》は、全体の中に本物の統一感を 作り出寸極めてモダンなエスプリの中に、バリエ (Louis Barillet 1880-1948)によって考案されている。(中略) バリエがクリエータ 一の一人 (彼以前にはポヴォルニ Povolny がブリュッセルで実現し た）である白いステンドグラスは、人工照明の中にその使用を見出 している。白いステンドグラスは、光に《ヴォリューム》を与える のである」(No.17) と、述べている。

ステンドグラスは通常色彩豊かであるが、マレニステヴァンスは 「白い理由として「(カテドラルやチャペルでは色彩豊かなステ ンドグラスが効果的だが）反対に、食堂や階段ではこの色彩の贅沢 は、ぜひとも必要ではない、むしろそれは有害である。空からテ 一ブルに、座る位置によって、顔が真つ赤や緑やサフラン色の招待 客をどう思うだろうか?人間の顔の上、壁や慣れ親しんだオブジェ の上にかかるこの虹は、なんとみじめな効果だろう。反対に、バリ エのような人間によって扱われた時、その芸術的価值とは别に、白 の特別なガラスでつくられたステンドグラスは照明として、たくさ んの有利な点を供する。《太陽のガラス》という、とてもイメージ に富んだ名前でより知られている、プリズムガラスは、その屈折の 切り子面の淤がで、偉大な自然光の部屋の中で、合理的に光線を 散乱させる。刻多付けられたガラスの無数の型は、様々な方向の中 に、外光も同様に配する。灰色を与えるこの多様なガラスの適切な 使用と、鏡の中に切られた破片と小さな不透明の要素の付加のおか げで、バリエは見事な品位と本物の美をもつステンドグラスをつく 
りあげた」(No.17) と述べる。このバリエの作品を、マレ＝ステヴ アンスは好んで自作に取り入れ、ひとつの特徵としている(12)。他に は、マレ=ステヴァンス通りの住宅群の中で採用されたジャン・プ ルーヴェ(Jean Prouvé 1901-1984)のメタルワーク等がある(図5)。 他分野の専門家との協㗢：上記のステンドグラスやメタルワーク を取り入れたように、画家や彫刻家といった芸術家、家具デザイナ 一、照明等の專門家、建設業者等との協働を強く勧め、自らの活動 においてそれを実践している。この協㗢の姿勢について、例えばス トックレー邸に感化され、映画セットに関わる中で強化されたのか 等、彼自身は述べていないが、他分野の専門家への共感や尊敬の念 が、UAMの設立や活動に現れており、これも建築家マレニステヴ アンスのひとつの特徵である。

とはいえ、この協働において全てを統括するのは建築家である、 というのが彼の考え方である。「もちろん建筑が命ずるのです。生 活状況によって、建設のプログラムは修正されるわけですが、椅子 は常に床から $44 \mathrm{~cm}$ のところに座面がある家具でなければならない でしょう。その唯一の様相は、建築の全般的傾向と流行によって修 正されるでしょう。本質的に、その目的によって、調度品は、それ が依存する建築に従うのです」（No.34）。よって、他の芸術家に委 ねられた装飾要素にも、マレ＝ステヴァンスの意向は十分反映され たと考えられよう。

\section{4. 造形に関する理念}

マレニステヴァンスの建築は「意味のない単なる箱の積み重ね」 (13)「形に凝り過ぎる」(14)といった批判をされることがある。彼は、 何を目的として複雑な叫凸を築くのであろうか。

彫刻的建築：著述の分析から、彼健築物を「彫刻」と考えると いうことがわかった。建築家はファサードにモールディングを刻 んで作る必要はない。建築家が彫刻する材料住宅そのものである。 突出部分と直線的なセットバックは、光と影の大きな面を形成する。 渦巻き模様や葉の花飾りのかわりに、他の滑らかな表面にぶつかる 滑らかな表面があるだろう。建築はモニュメンタルになったのだ」 (No.11)。「ペレ兄弟が、トニー・ガルニエが、ヴァン・ドウース ブルグが、ジャンヌレが建設するとき、彼らは巨大な㓮刻を築く。 光は、それがローランの石像やミクロスの金属製のブロックレリー フを照らすように、広い表面の上に作用するのである」(No.16)。 幾何学的形態：この彫刻的建築は、マレ=ステヴァンスの作品の 場合、アール・ヌーヴォーのそれのような淰意的な曲線とは無縁で ある。というのも、彼にとって建筑は基本的に幾何学的な芸術で ある。実際、壁は一般的に垂直である。床は水平である。柱は垂直 で、テラスと地面は水平であり、石のブロックは六面体で、空とド アは長方形、階段は水平面と垂直面で構成され、部屋の角々はほと んどいつも直角である。私達は直角が必要なのである」(No.11)。

この幾何学への志向をマレニステヴァンスは「新しい建築を生み 出さなければならない理由は、モダンライフに合致した美学をもつ という私達の絶対的必要なのである。機械は大勝利する。目は機械 の正確さとシンプルさを理解する。私達は自動車、機関車、飛行機、 電話、電気ラジェータ、ラジオアンテナの線に慣れている。私達は それらを好む。滑らかな表面、歯切れのよい連結、きれいなカーブ、 磨かれた材料、直角、明解さ、明瞭さ、秩序。これが論理的で呇何
学的な明日の家である」(№.11)、と理由づけている。 光に対する関心: マレ=ステヴァンスにとって、光は大きな関心事 である。それは「私は光に最も大きな重要性を認めた。これこそ、 可能な限りの照明の映画セットを確立し、いくつかの明るい家を建 設しつつ、私に映画におけるいくつかの成功をもたらしたものであ る」、「建築家は絶えず光のことを考えなければならない。これは 建築家の大きな関心事であるべきだ」(No.21)という発言や、「光に ヴォリュームを与える」という白いステンドグラスや、人工照明装 置の研究という活動加にもも具現化されている(図6)。

電話やエレベータや暖房装置と違って、「照明を決定するのは 建築家である。建築家は実際に構成する。トレラが言ったように《 形態は光と材料の交差点である》。もし、建築家が耐久性のある作 品をつくりたければ、彼はその両方とも、思うままにしなければな らない」(№.21、1928 年)。ここでマレニスデヴァンスが引用して いるのは、母校エコール・スペシアル・ダレシテクチュールの創設 者のエミル・トレラ (Emille Trélat 1821-1907)の言葉である。この 言葉は 1911 年の著述 (No.5) の中でも引用されていることから、 長年にわたってマレ＝ステヴァンスの心の中にあった言葉で、彼の 造形理念を表現するものの一つといえよう。

この光への関心は前項に記した「幾何学的な彫刻としての建築」 への志向と密接に結びいている。「近代建築は光を使って《演出 jouer》しなければならない。乙して、その配置と強さを建築家は位 置つけ調合する。光によって彼は素材の凹凸を蚛調したり、弱めた りする。彼は色彩を際立たせ、線を強調し、陽気さと快適さを創出 する」(No.21)、「影と光の大きな面を形成するために、調和をも って錯綜し、互いにずれている、統一された大きなマッスは、私達 の精神、私達の感性を満足させる。無駄なモチーフなしに、無益な 装飾要素なしに、ヴォリュームの配置のみによって得られる影の効 果」(No.10)、つまり、光は彫刻（二建築）が立体感を得るために 重要で、必要だということになる。

マレ=スデヴァンスの、この光への関心は、(1建物全体を照らし、 立体感を創出する自然光、そしてその自然光を利用する白いステン ドグラス、(2)室内を照らし、室内の立体感を創出する人工光（特に 間接照明へのこだわりは注目すべきである）、という二つの方向を もつ。(2)の人光、照明について、建築家の務めとして、彼は、(1) 目的に応じた必要照度の確保、(2)装飾要素、という2 点を挙げてい る(16)ことから実用と装飾を区別していることもわかる。

\section{5. 結}

マレ=ステヴァンスの近代建築の中心的概念は「モダンであるこ と」、つまり時代に合致していることが重要で、様々なスタイル を許容するものであり、絶対的な法則のように打ち出されるもので はなかった。装飾に関しても、よしとするものと否とするものは法 則によって決まっているのではなく、彼の感性によって決められる。 このため彼の建築は適切に理解されにくく、追従者を生みやすいも のとはなり得なかった。しかし、彼の視点による装飾の採用は、彼 の建築の評価を全面的に低めるとは言えず、むしろ他のモダニズム 建築にはない独特の優美さの獲得に寄与していると考えられる。

造形理念は一口に言えば、幾何学的な雕としての建築」であ る。拙稿「建築家R. マレ=スデヴァンスの映画セットに関する考 
察」17で明らかにしたように、映画セットの中心的な造形理念は「立 体感の創造」であり、建築のそれと「立体的なもの」という点で共 通し、これが造形志向の核心であろう。映画セットに関しては、幾 何学的形態や立体感の創造が、映画にいかに貢献するか、彼性扰 を示して合理的に説明している。この説明は実際の建筑物に心直接 は当てはまらないし、なぜ「幾何学的な彫刻としての建築」なのか という理由としては、対象とした著述のなかでは、「新しいニーズ と新しい技術によって生まれる新しい美学」といった記述位しか硋 当するものがない。少なくとも、マレ=スデヴァンスはなぜ自分の 建築が白い幾何学的な凹凹のある箱型なのか、そしてその形態がど のように決定されているのか、積極的に述べてはいない。この形態 の決定の手法については、図面資料に基ついた詳細な研究によって 今後検討する予定であるが、この形態が採用された理由について、 著述の分析から以下の 2 点が推測される。

まず、第一に、強いコントラストが生む美の愛好である(18)。建築 の幾何学的で変化に富んだ凹凸は光と影のコントラストを形成す る。白はこのコントラストを最も鮮やか心純粋に表現できる色であ る。もし、この光と影のダイナミックな作用と効果に主眼をおくな らば、建物全体にわたって装飾を施す必要はないのである。創意あ る芸術家による装飾要素が、居住者の生活空間に過剰にならずに彩 りを添えればよい。マレ=ステヴァンスの凹凹感のある白い箱型の 建築は、このような論理で強いコントラストへの愛好を満たしてい るのではないだろらか。第二に、清潔さや明瞭さを伴った建築表現 の愛好(19)である。白という色、幾何学的な形態が、この好多定満足 させ得るということは、十分想像できる。

著述では、彼の目指す近代建築と造形志向の閒をつなぐ合理的説 明、つまり機能と造形の関係は、明確に述べられていない。また、 都市や建築の経済性といった社会性の高い領域に、結果としてやや 消極的だったこともあり、従来十分に評価されてきたとはいえず、 また、彼の近代建築史における位置づけも曖昧である。しかし、彼 は、単なる国際様式の追従者でも、折袈主義者でもなく、独自の造 形を模索し、時代やライフスタイルの変化に敏感に反応し、より快 適でより豊かな生活空間の創造を目指して活躍していたことは、本 論で述べた通りである。マレ=ステヴァンスが近代建築の推進に貢 献したことは明らかであり、その作品の造形手法の分析等の研究を 通じて、今後より詳細に考察されるべき存在といえよう。

\section{注.}

(1) 主要な既往研究として、(1) Christian BONNEFOI, “Rob. MalletStevens; positions et contradictions de l'architecture Internationale" ,Thèse de doctorat, Université de Paris, 1974 (2) Rob.Mallet-Stevens architecte, Editions des Archives d'Architecture Moderne, Bruxelles 1980 (3) Jean-Francois PINCHON et al., Rob.Mallet-Stevens, architecture,mobilier, décoration, Philippe Sers Editeur, Paris 1986 (4) Cécile BRIOLLE,et al., La villa Noailles: Mallet-Stevens, Editions Parenthèses, Marseille 1990、が挙げられる。(1)はマレ＝ステヴ アンスの最初の包括的作品研究であり、その他の既往研究の基となるも のである。(2) 初めてのモノグラフで、掲載された写真・図版は現存す るものをほとんどカバーしている。(3)もモグラフで、複数の著者によ る様々な角度からのマレニステヴァンスの作品についてのエッセイを収 録している。(4)は、最初の実施作品である、ノアイユ子爵邸 Villa de Noailles の詳細な分析研究である。
(2) 著者はマレ=ステヴァンスの当時の活躍ぶりから推測して、既往研究で 知られている著述の数が少な過ざるのではないかと思い，まだ知られて いない著述を探すために、まず、マレニスデヴァンスが奇稿した可能性 のある年代 1900 年から 1945 年の間に刊行されていた建築・建設・美術・ 装飾に関する雑誌を、検索ソフト Ulrich's Plus 等在用いて、欧州、北米 の各国、日本について検出した。次にこれらの雑誌を、唡索ソフトMyriade を用いて、フランスの図書館等での収藏状況を調バた。その結果、調查 対象があまりに膨大で、その収蔵場所がフランス全土に分散し、個々の 収藏では欠本も多いことから、最終的には Myriade 等で得たデータを参 考に、美術・建築関係の雑誌が比較的ま乞まって多く収蔵されているパ リ市立フォルネイ図書館 (Bibliothèque Forney)、フランス建築学会 (IFA Institut Français d'Architecture) 図書館等で、所蔵雑誌を榆索・調查 した。

(3) アール・デコ博では観光館、パリ観光協会館、フランス大使館エントラ ンスホール、コンクリートのホの庭を、パリ万博では電気館、衛生館、 煙草館、民族団結館、フランスニブラジル・ルーヒー館を手掛けた。

(4) 前揭書 (1) O(2)、p.36

(5) Léon MOUSSINAC, Mallet-Stevens, Les Editions G. Crès\&Cie, Paris. 1931, p.6

(6) 搠稿「建築家 R. マレニステヴァンスの映画セットデザインに関する考 察」、日本建築学会計画系論文集 no.535

（7）例えば「(バリの任意の通りの一つ）をれを首都を知らない誰かに見せ てご覧なさい。彼はきっとあなたに、素晴らしいものも、調和の上れた ものもなにもない、と言うでしょう。パリはその広場、そのモニュメン ト、そしていくつかの街角によってしか美しくないのです」（No.19）と いった発言は、彼の都标観を同わせるものである。

(8) 例えば「マレニステヴァンスの名前は旗のようにたなびき、いつも少し きな臭い。近代芸術の中傷者の怒りをとり就招いているのが、マレ= ステヴァンス氏である。もっ乞も、彼は標的しして身をさらすこしを好 んでいるように思える。だから私は、彼が容易に生じさせた、この戦闘 的䨌囲気を彼が不快に思っていることに警いた」（No.34）といったイン タビュー記事の冒頭の文章に、彼の当時の活躍ぶりを知ることができる。

(9) マレ＝ステヴァンスは、「ある芸術は生まれたときはシンプルであるが、 徐々に装飾され、飾り過ぎになり、最後にはだめになってしまう」(No.29) と記述する。

(10)このマレ=ステヴアンスの志向については、前掲書(1)(3)中の、 Francois HEBERT-STEVENS, "La Thèorie architecturale de MalletStevens et la géométrie”,p.123でも同様の指摘がなされている。

(11) 原文 : Bonnier. Tony Garnier, Levart, Letrosne, Marini. les Perret, Plumet, Roubille, Ruaud, Sezille, Siclis, Thiers et plusieurs autres en France, Chiattone, Van Doesburg. Jeanneret, Oud, Sant Elia à l'étranger ont une même conception de I'architecture nouvelle.

(12) バリエの自邸 $(15$, sq.Vergennes, Paris 15e) も、マレースティ゙ァンス の設計である。現在はデナントビルになっていて往時の姿とは異なるが、 一部に「白いステンドグラス」を残している。

(13) H-R.Hitchcock Jr., Modern Architecture, Payson\&Clarke, New York, 1929 , p. 173

(14) Le Corbusier, "L'Exposition de l'Ecole Spéciale d'Architecture, L'Esprit Nouveau, no.23, Paris, 1924

(15) マレニスデ゙ァンスの照明の研究に対する真摰な姿勢と知見は、No.21、 No.38によく現れている。No.21 は照明専門誌に掦載されたものである。 また、照明技術者アンドレ・サロモン André SALOMON(1891-1970) と 祭密に協働している。(図6)の作品も彼との協働である。

(16) No.21

(17) 前掲畫(6)

(18) “Le noir et blanc"（Tekhnè, no34,16nov 1911）の中で「全ての建築の 装飾、彫刻、装飾は白と黒の対立に基づいている。エミール・トレラが 「形態は光と材料の交差点である」と言ったように。芸術家にとって解決 すべき問題は、適切に調和をもって素材の塋出部分とへこみを配置するこ とである。そして物体を描く光と影によってしか、それらは真価を発揮し ないし、本領を発揮しないのである」と述べている。そしてまた、甥の Jean Manusardi 氏はマレンステヴァンスとの思い出を記した文章（前掲畫(1) (3) p.144) の中で、「(彼の死の間際に) 彼が私に話しがけた最後の言葉 は日本の和歌の感動的なシンプリシティを持っていた。：「多分、私は二 度と落日の雪にささる杭の鮮明な影を見るこしはないだろう」」と書いて いる。人生の最後においても、鮮明なコントラストのイメージは彼の心か ら離れなかったのである。

(19) 彼のこの志向は、著述の中でしばしば読み取れるものであるが、具体的 には例えば、(あるインタビューで、パリ市の新しいビルについて意見を求 められ)「気に入りません。全てが様々な家が建てられますが、私は本当に 線が整っているのが好きなのです」（No,19）といった発言によく表れて いる。 